\title{
"The Milk of Birds": A Proverbial Phrase, Ancient and Modern, and its Link to Nature ${ }^{1}$
}

\author{
By Martha J. Payne*
}

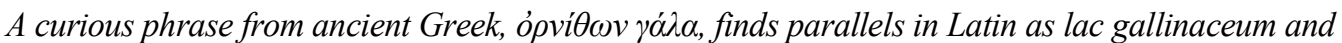

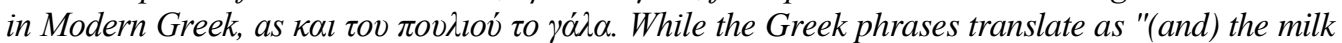
of (the) bird(s)", the Latin translates as "hen's milk". This essay discusses the phrase in a select variety of Greek and Latin sources from the 5th century BCE to the 4th century CE, and its Modern Greek equivalent in the 21st century. In addition, it discusses the variety of meanings and uses found in those sources, and connections to the natural world. Information from ancient sources has been gleaned from a search of the Digital Loeb Classical Library online database. Information for modern use comes from informal interviews, Facebook messages, e-mails, and telephone messages of nine native speakers of Modern Greek from different parts of the Greek world, most of whom live in the United States. The essay discusses two points concerning the natural world: first, the phrase as found in the names of certain plants, and second, as a substance called crop-milk produced by members of the pigeon family. The linguistic connection between ancient and modern worlds and the parallels found in nature encourage scholars to look "outside the box" when investigating proverbs, proverbial expressions and proverbial phrases. The Modern Greek version of the phrase both confirms and expands the meanings of the ancient ones, thus suggesting that other connections between these ancient and modern languages may prove to be fruitful avenues of investigation.
\end{abstract}

Keywords: Ancient Greek, Latin, Modern Greek, Natural word, Proverbial expression

\section{Introduction}

A curious phrase from ancient Greek finds parallels in Latin and in Modern Greek. In ancient Greek the phrase is ópví $\theta \omega v$ yó $\lambda \alpha$ ("milk of birds"),

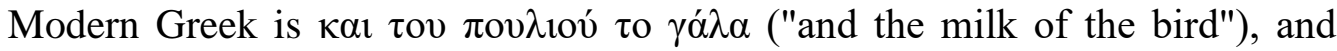
Latin is lac gallinaceum ("hen's milk"). Despite variations, all examples imply contradictory ideas of rarity and abundance. Since the phrase seems to indicate something so rare that it does not exist, someone who says that s/he has something as rare as birds' (or hen's) milk is indicating that $\mathrm{s} / \mathrm{he}$ has an abundance of anything that someone would want, even the rarest of items. The purpose of this essay is to discuss the sources and uses of the phrase birds' (hen's) milk in the ancient languages, showing how the modern use throws light on ancient usage, and how birds' milk appears in nature and may be the source of the phrase.

\section{Methodology}

I have collected examples of ancient uses of the phrase birds' (hen's) milk using a search of the Digital Loeb Classical Library online database. The sources are: Greek - Aristophanes; Eupolis in Diogenianus; Mnesimachus in

\footnotetext{
${ }^{*}$ Visiting Lecturer, Indiana University-Purdue University at Indianapolis, USA.

${ }^{1}$ This essay developed from a graduate paper in Linguistics at Ball State University. My thanks to Dr. Elizabeth Riddle for her encouragement
} 
Athenaeus; Menander in Strabo; Lucian; Libanius; Latin - Pliny the Elder; Petronius. Examples from Modern Greek come as anecdotal evidence primarily from informal interviews with native Greek speakers from different parts of the Greek-speaking world: Northern Greece (Thessalonike; Katerini); Central Greece (Athens); Peloponnesos (Sparta); Islands: (Andros ${ }^{2}$; Carpathos; Cyprus). Most of the informants are members of Holy Trinity Greek Orthodox Church, Carmel, Indiana. Examples from other informants come from e-mail and Facebook communications. To protect the informants' identify, I have labeled them "Informant 1, Informant 2, Informant 3, etc". See Table 1 for gender and place of origin.

Table 1. Key to Informants

\begin{tabular}{|l|c|c|}
\hline Informant 1 & Male & Thessalonike \\
\hline Informant 2 & Female & Thessalonike \& Katerini \\
\hline Informant 3 & Female & Athens \& Karpathos \\
\hline Informant 4 & Male & Athens \\
\hline Informant 5 & Male & Athens \\
\hline Informant 6 & Female & Sparta \\
\hline Informant 7 & Female & Nicosia, Cyprus \\
\hline Informant 8 & Male & Nicosia, Cyprus \\
\hline Informant 9 & Female & Limassol, Cyprus \\
\hline
\end{tabular}

\section{Literature Review}

Ancient Greek proverbs and proverbial expressions have been discussed from the time of Aristotle. In fact, Jan Fredrik Kindstrand notes that Aristotle wrote a work on proverbs which is no longer extant ${ }^{3}$. More recent studies, such as that by André Lardinois (2001), discuss the orality of proverbs; other studies focus on specific proverbs. Susan Shapiro, discusses contradictory proverbs, specifically, $\gamma \nu \omega \mu \alpha i ́ / g n o m a i$ in Herodotus (Shapiro 2000: 89); in discussing the proverbs in Strabo's Geography, Daniela Dueck examines how proverbs and the background stories that go with them add interesting and entertaining narrative variation to Strabo's presentation of different geographical areas (Dueck 2004: 53). Johannes Foufopoulos and Nikos Litinias (2005), study proverbs treating crows and ravens from ancient and Modern Greek, Latin and Egyptian Arabic; they discuss how the natural history of those birds influences the proverbs. Everett Wheeler's article (1988) "По $\lambda \lambda$ ò

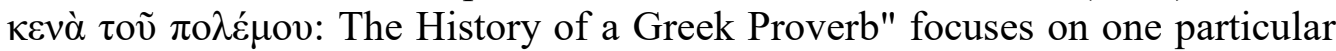

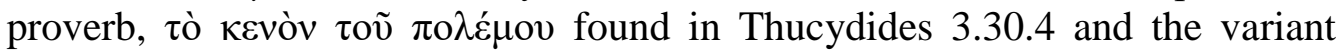
form, $\pi 0 \lambda \lambda \grave{\alpha} \kappa \varepsilon v \grave{\alpha} \tau o \tilde{v} \pi 0 \lambda \hat{\varepsilon} \mu o v$, and the meaning it took in antiquity.

Modern scholars, have their own definitions for the term "proverb" in ancient Greek. Joseph Russo defines a proverb "... as a well-shaped complete

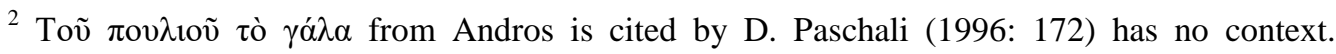
However, Paschali cites parallels from Aristophanes, Strabo, Athenaeus, Petronius and Pliny.

${ }^{3}$ Kindstrand (1978: 74), citing the testimony of Diogenes Laertius 5.26, and Athenaeus 2.56.60 d-e.
} 
sentence ... stating a general truth that everyone would accept as important and useful to recall" (Russo 1983: 121, Dueck 2004: 41). In addition, Russo states that a proverb is brief and concise (Russo 1983: 122). According to Kindstrand, proverbs have four characteristics they: 1) are popular, 2) have a specific form (Kindstrand 1978: 71), 3) express some aspect of old wisdom and 4) "... are often supposed to express a truth" (Kindstrand 1978: 77, Dueck 2004: 41). Kindstrand also notes that proverbs are likely to be "... rooted in the language of the poorly educated [in ancient Greece]". He supports this view first noting that proverbs were popular in comedy and mime, "... forms of literature which reproduce the language and thought of the common people" (Kindstrand 1978: 72, Dueck 2004: 41), and second by noting that Plato used proverbs frequently "... as an element of the spoken language in order to give his dialogues a more authentic character ..." (Kindstrand 1978: 73). Dueck adds to the discussion in saying that one way proverbs were used was "for rhetorical and didactic purposes" (Dueck 2004: 41). Recalling this point and the concept of a proverb as an expression of a truth will be useful in examining some examples some from late antiquity and some from nature.

The phrase ópví $\theta \omega v$ yó $\lambda \alpha$ fits the first of Kindstrand's categories, i.e. its popularity, as witnessed by its appearance in comedies and mimes, reflecting the common speech of the time. That it appears in comedies of Aristophanes, Mnesimachos and Eupolis ${ }^{4}$ is testimony supporting this criterion. The fact that

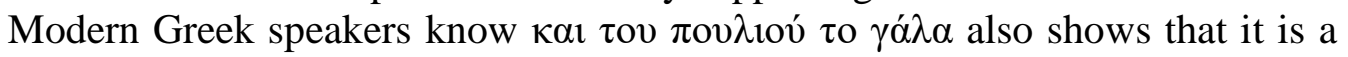
modern popular expression. However, the phrase also fits the category of revealing some aspect of wisdom and truth as will be shown below.

\section{Use of Proverbs/Proverbial Expressions Over Time}

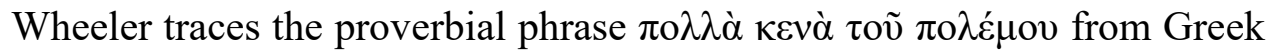

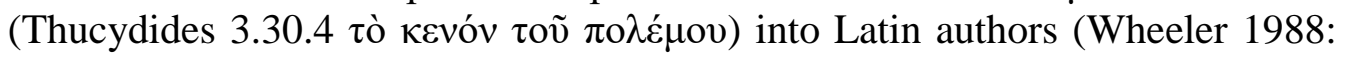
155-160) noting variations in meaning, first explaining it as "fog of war", after a term used by military strategist Carl von Clausewitz (Wheeler 1988: 181), but also as an expression indicating panic (Wheeler 1988: 172-173). Wheeler notes this later association eventually became a proverb for peripatetics passing

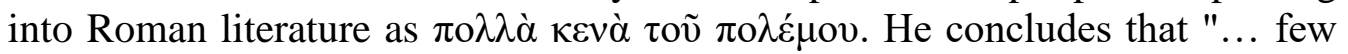
Greek proverbs have such a traceable history (Wheeler 1988: 184)".

Accepting Wheeler's premise that few ancient Greek proverbs can be traced into later periods, in looking over Strömberg's collection of over 300 Greek proverbs from antiquity into the Byzantine period one sees that only three have counterparts in Latin, and Modern Greek (Strömberg 1954: 42-43) ${ }^{5}$.

\footnotetext{
${ }^{4}$ Aristophanes, Av. 729-736; 1665-1763; Vesp 504-511; Mnesimachos Phillipos frg 9 FCG iii

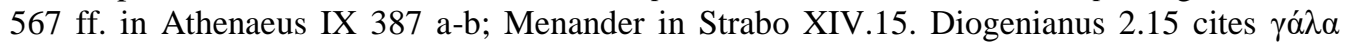
ópví $\theta \omega v$ (milk of birds) from a comedy of Eupolis (fragment 411) (Storey 2011: 262). Unfortunately there is no context for further comment except that it is another ancient Greek example from comedy.

${ }^{5}$ Eustathius \#8; p. 62, Phocylidea \#2; p. 68, Plutarch \# 1.
} 
Further support may be found in proverbs concerning crows and ravens collected by Foufopoulos and Litinias. Of 17 Latin proverbs or proverbial

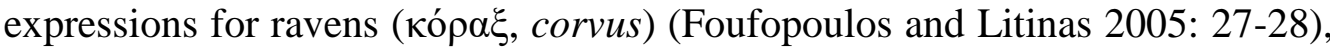
only three have Classical (Foufopoulos and Litinas 2005: 27) or Byzantine Greek parallels (Foufopoulos and Litinas 2005: 26). Similarly, of nine Latin

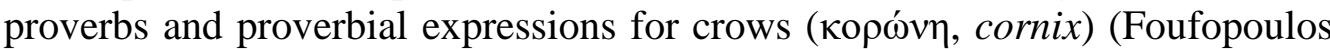
and Litinas 2005: 30-31) only two have counterparts in Classical or Byzantine Greek (Foufopoulos, and Litinas 2005: 30). None have counterparts in Modern Greek or Arabic. The proverbial expression birds' milk fits in as one of those seemingly rare examples whose history can be traced from ancient Greek, to Latin to Modern Greek.

\section{Meaning}

The phrase for birds' milk in all three languages has a variety of meanings, some specific and some general. The general meaning refers first to someone who possesses an abundance of items, often rare, or impossible. For example, the $4^{\text {th }}$ century CE. Syrian rhetorician, Libanius, in one of his letters, uses the phrase birds' milk as a comment on the character of the citizens of Apamea, who continued to worship the pagan god Zeus, thus doing something nearly impossible for the time period (Libanius, Letter 104.3 - to Alexander):

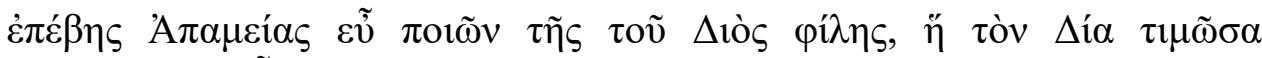

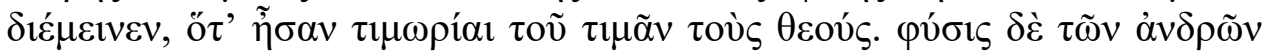

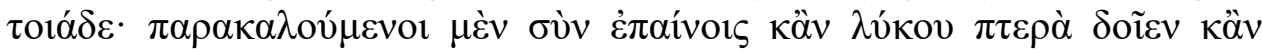

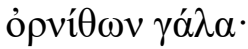

You visited Apamea, and very properly, for she is dear to Zeus and continued to reverence Zeus when punishments were reserved for reverencing the gods. But the character of the people is of this sort; if they are encouraged and praised, they will do anything - even the impossible ${ }^{6}$.

Presumably, Libanius makes this comment because at the time Christianity was beginning to take hold of the Roman Empire, and those worshipping the pagan gods were being persecuted.

But the phrase also implies that one has so many things available that one could have whatever one would want, even the rarest item. While this is one Modern Greek understanding ${ }^{7}$, as will be seen, the concept can also be applied to ancient Greek and Latin, but with a twist.

\footnotetext{
${ }^{6}$ Libanius, Letter 104.3 - to Alexander. trans. A.F. Norman. Cambridge, MA. 1924. All ancient Greek and Latin texts come from the editions of the Digital Loeb Classical Library. Except where otherwise noted, translations also come from these editions. The last line "... they will do anything — even the impossible" is more literally translated as "... they would even give wolf feathers and the milk of birds". Trans. M. Payne.

${ }^{7}$ Informants 2 and 3 (pers. com 14 August 2016); Informants 1 and 4 (pers. com. 21 August

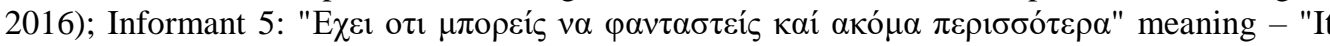


Many of the examples of the birds' milk phrase concern food, particularly food that is rare or extremely good. For example, Athenaeus in discussing

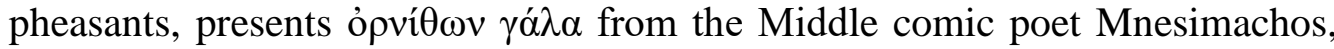
found in a fragment of the play Philippos (frg. 9, FCG iii. 567 ff.) where Mnesimachos says birds' milk is a rare item (Ath. IX 387 b):

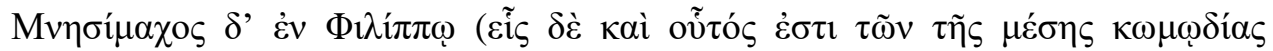

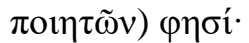

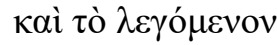

$\sigma \pi \alpha v i \omega ́ \tau \alpha \tau o v \pi \alpha ́ \rho \varepsilon \sigma \tau ı v ~ o ̉ \rho v i ́ \theta \omega v ~ \gamma \alpha ́ \lambda \alpha$,

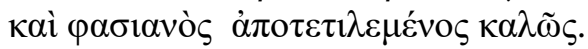

Mnesimachus, in Philip (he is one of the poets of middle comedy) says:

And the saying (thing that is said) is

The milk of birds is rarest thing there is

and a well-plucked pheasant. (Trans. M. Payne) ${ }^{8}$

While birds' milk as a rare food is not specified, because it is in contrast with a pheasant presumably plucked for cooking, and the fact that the passage following this one discusses a gourmand, ( $\gamma \alpha \sigma \tau \rho i ́ \mu \alpha \rho \gamma 10 \varsigma)$ Leagros, one imagines that food is implied.

The concept of something rare, exceptional, or the best, is one underpinning other examples. Connected to the concept of rarity is the idea that someone has everything possible, including birds' milk, and hence one has an abundance. Strabo hints at this abundance when he cites the phrase from Menander in commenting on Samos' blessings (Strabo XIV.15):

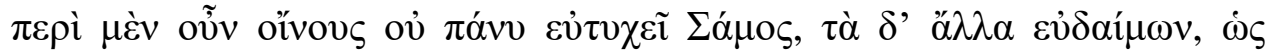

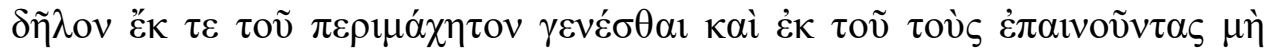

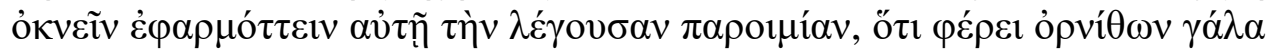

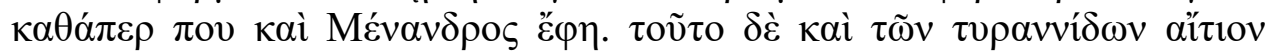

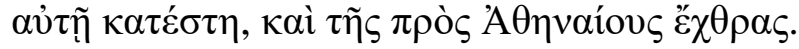

Now Samos is not altogether fortunate in regard to wines, but in all other respects it is a blest country, as is clear from the fact that it became an object of contention in war, and also from the fact that those who praise it do not hesitate to apply to it the proverb that "it produces even birds' milk", (sic) as Menander somewhere says. This was also the cause of the establishments of the tyrannies there, and of their enmity against Athens ${ }^{9}$.

has whatever you can imagine, and even more" (Facebook message 15 August 2016). Modern Greek translation M. Payne.

${ }^{8}$ Ath. IX 387 a-b. The translation given by S. D. Olson in the Loeb Classical Library edition is a bit different: "Mnesimachus, (another Middle Comedy poet) says in Philip (frg. 1)/There's birds' (sic) milk/Which is said to be the rarest food there is, and a nicely plucked pheasant". S. D. Olson, Cambridge, MA., 2008, p. 295.

${ }^{9}$ Strabo XIV.15. Trans, H.L. Jones, Cambridge, MA., 1929. 
It is unclear what items Samos produced that Strabo felt deserved high praise, but it is not the wine. However, Strabo notes that Samos has other valuable resources ${ }^{10}$, which may have been used for food production, and these were the reasons for certain political events, namely the establishment of tyranny on the island and Athenian-Samian hostility. Similar concepts of rarity can be found in the Latin variations of Pliny the Elder and Petronius. In his comments about the titles that Greeks give to books, Pliny notes that they are so imaginative, one might hope to find rare items including, birds' milk ( $H N$, Praefatio 24):

Inscriptionis apud Graecos mira felicitas: күрíov inscripsere, quod

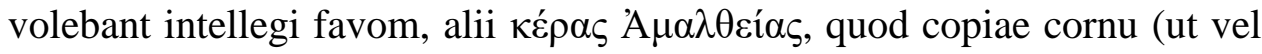
lactis gallinacei sperare possis in volumni haustum) ...

There is a marvelous neatness in the titles given to books among the Greeks. One they entitled Knpíov, meaning Honeycomb; others called their work Képas 'A $\mu \alpha \lambda \theta \varepsilon i ́ \alpha s$, i.e. Horn of Plenty (so that you can hope to find a draught of hen's milk ${ }^{11}$ in the volume), ...

Again, food is not specified directly, but the references to honeycomb and the horn of plenty, which was said to provide an abundance of the fruits of the earth, lead one to make a food connection.

About one hundred years later, Lucian seems to have been influenced by Pliny in his satirical piece On Salaried Poets in Great Houses. There he states that a poet who has found employment with a good master will have gained the horn of plenty and birds' milk, apparently achieving all that he could desire (On Salaried Poets in Great Houses 13):

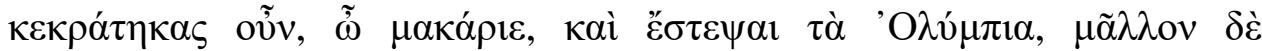

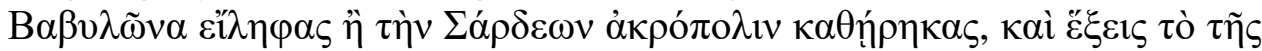

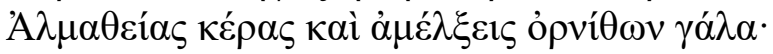

You have won, then, lucky man, and have gained the Olympic crownnay, you have taken Babylon or stormed the citadel of Sardis; you shall have the horn of Plenty (sic) and fill your pails with pigeon's (sic) milk ${ }^{13}$.

\footnotetext{
${ }^{10}$ Barber (1987: 705), comments that Samos was known for its fertility. Samos produces a sweet wine that has a good reputation.

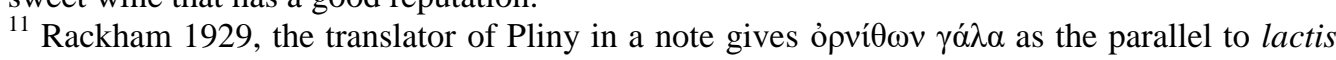
gallinacei and then comments that it is "a proverbial rarity like pigeon's (sic) milk", p. 15, note b. M. Heseltine, the translator of Petronius Satyricon, makes no such comment.

12 Pliny, HN, Praefatio 24. Trans. H. Rackham, Cambridge, MA., 1938. Capitalization in the translation is as it appears in the Loeb edition.

${ }^{13}$ Lucian On Salaried Poets in Great Houses 13. Ttrans. A.M. Harmon, Cambridge, MA.,

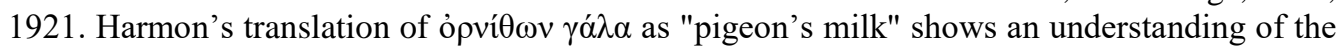
true meaning of the phrase.
} 
Petronius, on the other hand, comments on the abundance of material that Trimalchio produces on his property, even the rarest item, hen's milk; why, Trimalchio does not even need to go shopping (Petr., Sat. 38):

Nec est quod putes illum quicquam emere. Omnia domi nascuntur: laina, credrae, piper, lacte gallinaceum si quaesieris, invenies.

You must not suppose either that he buys anything. Everything is homegrown: mastich, citrons, pepper; you can have hen's milk for the asking $^{14}$.

In Modern Greek, concepts of abundance take interesting turns. One view

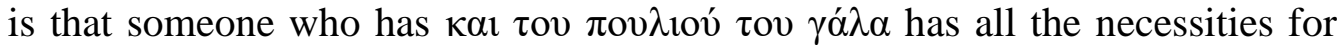
living. This interpretation can be applied when refering to how a child has been

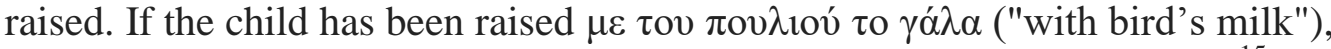
then s/he has been raised with everything s/he could possibly need ${ }^{15}$. In contrast, the phrase can also have a negative connotation. One Greek speaker

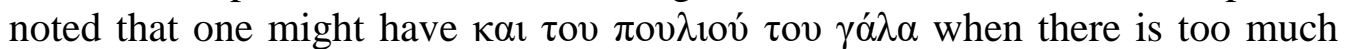
abundance $^{16}$. Neither interpretation is found in the ancient sources.

The expression takes on a further meaning in three examples from Aristophanes, Birds, and Wasps, and from Modern Greek, namely, as a means of persuasion. Shapiro notes that proverbs may contain an element encouraging behavior modification (Shapiro 2000: 93) and that is precisely the goal in the Aristophanes examples. In Birds the Leader of the Chorus of Birds attempts to encourage humans to join their flock by offering the enticement of birds' milk (Av. 729-736):

\section{Kopvpaíos}

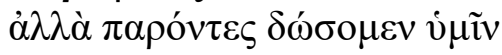
$\alpha u ̛ \tau o \tilde{\iota} \varsigma, \pi \alpha \iota \sigma^{\prime} v, \pi \alpha i \delta \omega v \pi \alpha \imath \sigma i ́ v$,

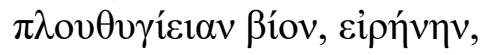

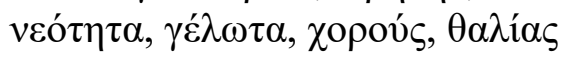

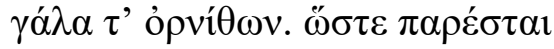

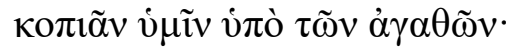

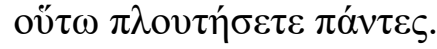

\section{Chorus Leader}

... but ever at hand we'll bestow on you, your children, and your children's children, healthy wealthiness, happiness, prosperity, peace, youth, hilarity, dances, festivities, and birds' milk. Why, you're liable to knock yourself out from good living, that's how rich you'll be ${ }^{17}$.

\footnotetext{
${ }^{14}$ Petronius, Sat. 38. Trans. M. Heseltine, Cambridge, MA., 1913.

${ }^{15}$ Informant 7, e-mail com. 5 August 2016; Informant 8, e-mail com. 8 August 2016.

${ }^{16}$ Informant 1, pers. com., 21 August 2016.

${ }^{17}$ Ar. Av. 729-736. Trans. Jeffrey Henderson, Cambridge, MA., 2000.
} 
Similarly, somewhat later, Peisetaerus also offers the birds' milk to Herakles as an inducement to join the flock of birds ( $A v$. 1665-1673):

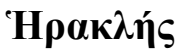

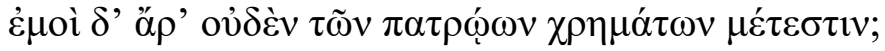

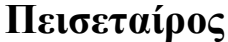

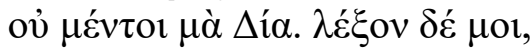

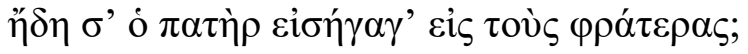

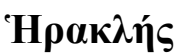

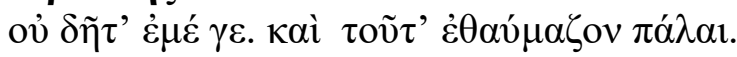

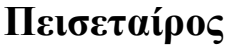

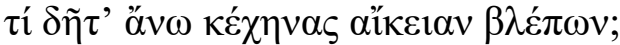

$\dot{\alpha} \lambda \lambda \lambda^{\prime} \hat{\eta} v \mu \varepsilon \theta^{\prime} \dot{\eta} \mu \tilde{\omega} \nu \tilde{\tilde{n}} \varsigma, \kappa \alpha \tau \alpha \sigma \tau \eta \dot{\sigma} \sigma \alpha \varsigma \sigma^{\prime} \dot{\varepsilon} \gamma \grave{\omega}$

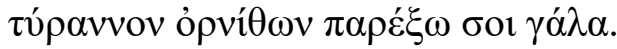

\section{Herakles}

You mean I have no share in my father's property?

\section{Peisetaerus}

Absolutely none. Tell me, has your father inducted you into his phratry yet?

\section{Herakles}

Not me he hasn't, and that's always made me wonder.

\section{Peisetaerus}

So why gape at the sky with an assaultive glare, when you could side with us? I'll appoint you ruler, and supply you with birds' milk ${ }^{18}$.

Again, in neither case is food overtly mentioned, but the references to celebration of a party in the first example, leads one to think of food. Making Herakles tyrannos in the second passage leads one to think Herakles could have whatever he wanted, even whatever food.

In Modern Greek also, the phrase can be used as an enticement. For

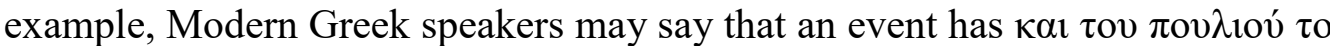
$\gamma \alpha \dot{\alpha} \alpha$, when making an invitation ${ }^{19}$. In that situation, the phrase is intended to encourage invitees to attend presumably because there will be many wonderful things to eat and drink.

The concept of abundance, enticement and shopping can be seen in Petronius, and in other situations in Modern Greek. Just as Petronius' Trimalchio has so much material on his estate that he does not need to go

${ }^{18}$ Ar. Av. 1665-1673. Ttrans. Jeffrey Henderson, Cambridge, MA., 2000.

${ }^{19}$ Informants 2, 3 and 9, Pers. com. 14 August 2016. 
shopping, the bird's milk phrase in Modern Greek can refer to a special type of grocery store that not only has the best products but also anything one could want $^{20}$. As an enticement, this phrase is even used an advertisement. In a blog on the Foursquare website for the $\mathrm{AB}$ Vassilopoulos grocery store chain in Greece, a reviewer for AB Pefki (Athens), commented that the store has "kai tou pouliou to gala!!!" (sic), ("it even [has] bird's milk!") ${ }^{21}$. In actuality, the

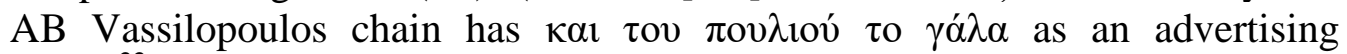
$\operatorname{slogan}^{22}$.

In ancient Greek in Aristophanes' works, results of the enticements from the phrase vary. In the Birds the enticements succeed, and the people invited to join the bird flock do so. However, in Wasps, birds' milk is mentioned for a slightly different reason: as a refusal to leave a group, rather than an enticement to join one. Loathecleon wants his father, Lovecleon, to live a quiet, "genteel life" and to stop his daily hobby of serving on Athenian juries. But Lovecleon refuses, responding that even if Loathecleon offered him birds' milk he would not stop (Vesp. 504-511):

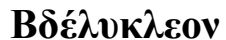

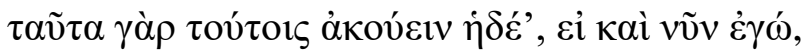

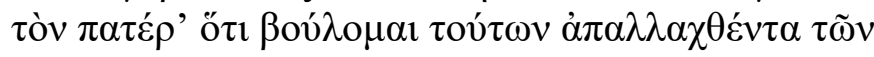

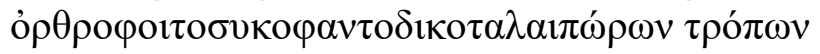

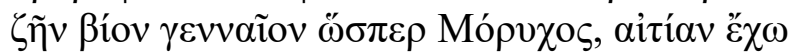

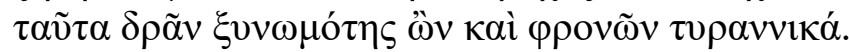

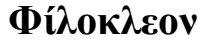

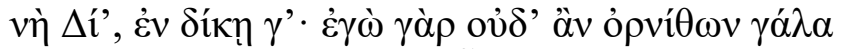

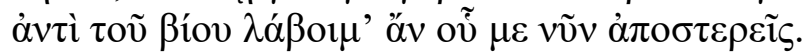

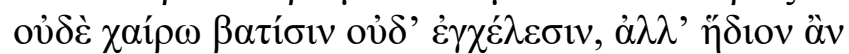

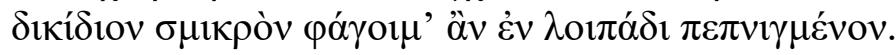

\section{Loathecleon}

Yes, these people enjoy hearing talk like that, if my present case is any indication. Just because I want my father to quit his

\footnotetext{
${ }^{20}$ Informant 7, e-mail com. 5 August 2016; Informant 6, voice-mail message 15 August 2016. I am reminded of a slogan used as an advertisement for Ball State University from 1998-2006: "Everything you need". (Jennifer Criss Office Services Coordinator, Division of Strategic Communications, Ball State University cites Michael Szajewski, Bracken Library,-(e-mail com. 8 August, 2016).

${ }^{21}$ Nikos Koui, Amaroúsion, Greece. 31 January 2013. goo.gl/UhmPDn. 14 August 2016. See also

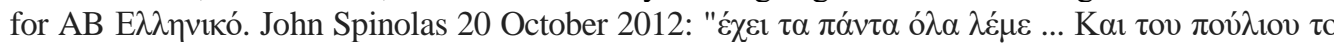

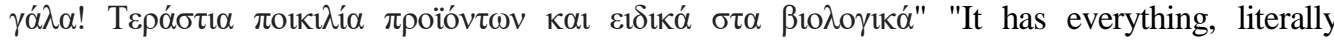
everything ... even bird's milk! [There is] an enormous variety of produce and organic products". (Trans. Artemis Achilleos-Nicolaou - e-mail message 20 Mar. 2017). goo.gl/dESqjN. 16 March 2017.

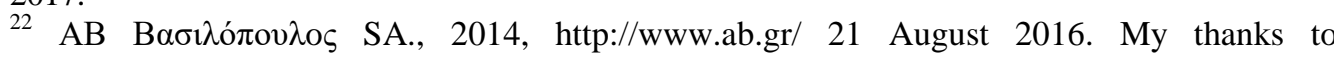
Chrysostomos Giannoulakis and Mixalis Poulakis for this reference (pers. com 21 August 2016). See also D. Charontakis (2014, October 15), announcing the opening of a remodeled AB Vassilopoulos store in Athens.
} 
dawn-wandering, nuisance-suing, jury-serving, trouble-seeking habits and live a genteel life like Morychos, for my efforts, I get called a conspirator with tyranny in mind

\section{Lovecleon}

Yes, and rightly so! For pigeons' milk ${ }^{23}$ I wouldn't trade the living you'd take me away from now. Skate and eels don't tempt me either. I'd much rather sit down to a nice little lawsuit baked en casserole $^{24}$.

\section{Nature}

In commenting on the Strabo example from Menander, Dueck notes the expression birds' milk as it applies to Samos is "... a comic comment ..." and "an exaggeration, "... since birds do not provide milk". Following Pliny, she notes "... even non-existent things may be found ..." in the books of the Greeks (Dueck 2004: 47). Indeed, if she were to look at the Latin variations of the phrase, lac gallinaceum, hen's milk, she would be quite correct. However, as we shall see, there is more to the story, since there is a connection to the phrase in nature.

Birds' milk can be found in a variety of ways in nature. In Greece and Cyprus, a small spring flower, a member of the Lily family, is called Ornithogalum, known in English as the Star of Bethlehem (Polunin 1980: 494495). Around a dozen species are found in Greece (Sfikas 1978: 82) and at least five on Cyprus (Sfikas 1990: 308). Both Nicander of Colophon and Pliny mention plants by that name. First, Nicander: (Georgics - fragments in Ath. IX. 371c):

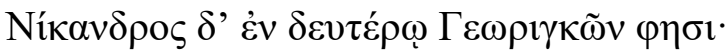

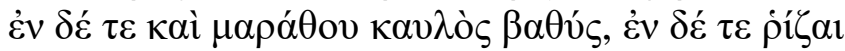

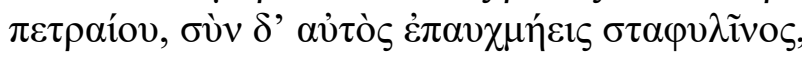

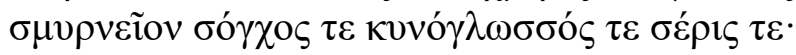

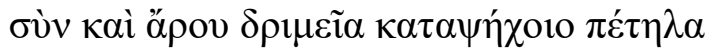

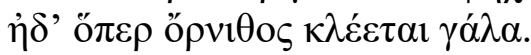

Nicander says in Book II of the Georgics (fr 71 Schneider):

and among them high fennel-stalk, and among them also roots

of stone sperage, and with them the shaggy carrot itself,

Cretan alexander, and sow thistle, and dog's tongue and endive;

you might also grind up the pungent leaves of cuckoo-pint along with

them, or what is referred to as bird's milk ${ }^{25}$.

${ }^{23}$ Curiously, in his translations of Aristophanes, Henderson gives "pigeons' milk" for the passage in Wasps, (1998, p. 285) but "birds' milk" for his translation in Birds (2000, pp. 121, 241). The translation as "pigeons' milk" shows that the translator is aware of pigeon natural history, which will be discussed in this essay.

${ }^{24}$ Ar. Vesp. 504-511. Trans. J. Henderson, Cambridge, MA., 1998. 
In listing several plants of a particular genus, Pliny the Elder also mentions one called bird's milk (HN I.XXI.lxı):

Spicatarum genera: stanyops, alopecuros, stelephuros sive ortyx sive plantago, thryallis; perdicium, ornithogale;...

Ear-bearing classes: stanyops, fox-tail, stelephuros, or quail-plant or plantain, thryallis, partridge-wort, bird's milk;... ${ }^{26}$

In looking at how the term is used in connection with birds in ancient Greek, Anaxagoras as cited in Athenaeus, notes that the phrase refers to eggwhite (Ath. II.57d):

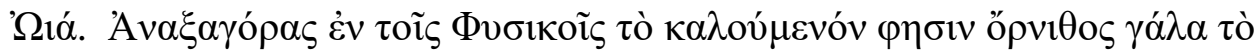

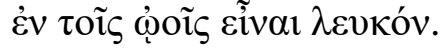

Eggs: Anaxagoras in his Physics (59 B 22) says that what is referred to as bird's milk is actually egg-white ${ }^{27}$.

However, there is more to learn from examining other biological connections with birds. It is interesting to note that all Greek examples for the phrase birds' milk refer not to a specific bird, but to birds in general: oै $\rho v \varsigma^{28}$ in Ancient Greek, and $\pi$ ov $\lambda i$ in Modern Greek. In contrast, the Latin is gallinaceum "hen". While it seems that such an object as birds' milk would not exist, as Dueck notes (2004: 47) (and indeed it does not in chickens) since birds are not mammals, nevertheless, in nature, something does exist that may have been the source of the proverbial phrase. The substance is called "crop milk" which is produced by pigeons and doves (genera Columba and Streptopelia in the family Columbidae $)^{29}$. Both wild and domesticated pigeons and doves ${ }^{30}$ were well-known to the ancient Greeks; both were used for food and the domesticated birds were also popular as pets (Lamberton and Rotroff

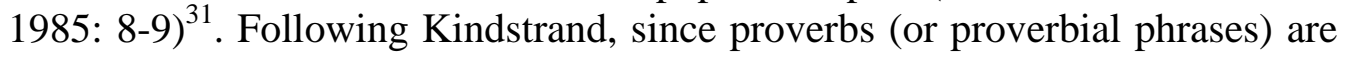
"... rooted in the language of the poorly educated [in ancient Greece] ..." reflected in the popular language of comedy (Kindstrand 1978: 72), and express a truth (Kindstrand 1978: 77), we might expect that people of

\footnotetext{
${ }^{25}$ Nic. Georgics fragments in Ath. IX. 371c. Trans. S.D. Olson, Cambridge, MA., 2008.

${ }^{26}$ Plin. HN Book 1, trans. H. Rackham, Cambridge, MA., 1938.

${ }^{27}$ Anaxagoras in Ath. II.57d, trans. S. D. Olson, Cambridge, MA., 2007.

${ }^{28}$ According to Liddell and Scott 1940 A Greek-English Dictionary, s.v. ö $\rho v i s$, the word can apply to any bird, even domestic fowl and birds of prey. In Cypriot Greek the word ópvi $\theta \alpha$ can refer to chickens. Informant 9, e-mail message 16 March 2017.

${ }^{29}$ Two other species of birds, flamingos and emperor penguins also produce a similar substance for their young, but it is produced from the esophagus, not the crop (Winkler 2004: 8-133).

${ }^{30}$ Ath. (IX.393f-394a), in quoting Aristotle, notes that there was but one genus of pigeons, but five species (Levi 1974: 41). Cramp et al. (1985: 284) comment that the terms "pigeon" and "dove" are synonyms, with "pigeon" used for larger-sized species and "dove" for the smaller.

${ }^{31}$ Wild birds of many types are hunted in Greece. Handrinos and Akriotis (1997: 316) list some 31 species, including four species of pigeons/doves that could be hunted.
} 
Aristophanes' time were familiar with crop milk from slaughtering, butchering and cooking these birds.

Crop milk (aka pigeons' milk) is produced by both cock and hen pigeons/doves to feed their newly hatched chicks. Crop milk production is stimulated by the hormone prolactin from the anterior pituitary gland (Evans and Heisser 2004) ${ }^{32}$ and is produced from the lining of the crop (Winkler 2004: 8-133, Levi 1974: 267). Crop-milk formation starts about the $8^{\text {th }}$ day of brooding (Levi 1974: 266) and by day 18 the nutritive layer of the crop lining breaks down and sloughs off fat globules. The whitish masses of dead cells comprise crop milk (Levi 1974: 268). The composition of this substance is protein and fat; there are no carbohydrates (Levi 1974: 268). In addition it contains vitamins A \& B and has more protein than human milk (Evans and Heisser 2004). Like other seed-eating birds, pigeon chicks are not fed insects so crop-milk provides an important source of protein (Ehrlich et al. n.d.). The chicks are fed by both sexes (Levi 1974: 267) ${ }^{33}$, with the chicks taking the substance directly from the mouths of their parents. About the $3^{\text {rd }}$ or $4^{\text {th }}$ day after the chicks have hatched, grain is mixed in with the crop-milk (Levi 1974: 268). About 6-7 days after the chicks have hatched, production stops (Levi 1974: 268). According to pigeon expert, Wendell Levi, crop-milk is cream-colored and is similar in appearance and consistency to curd (Levi 1974: 267). Possibly the color and the fact that the hormone that stimulates milk production in mammals stimulates production are the reasons why the substance is dubbed "milk".

When reviewing Aristotle's Historia animalium one wonders why Aristotle did not pick up on the concept of birds' milk. From his analysis of the internal organs of pigeons, it seems that he has some experience dissecting these birds (Arist. HA II.XVII. 508b.26-29) 34. $^{34}$.

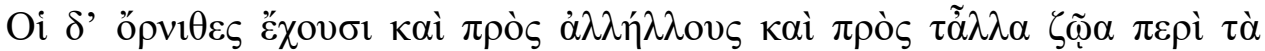

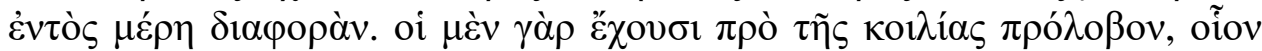

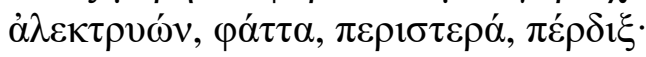

Birds differ both from each other and from, the other animals in respect of their internal parts. Some for instance have a crop in front of the stomach, as the domestic fowl, the ringdove, the pigeon, and the partridge ${ }^{35}$.

Either Aristotle did not dissect the crop, although, he does say it is hollow and that food comes into it first (HA 508b.29-30), or if he did perform such a dissection, he may have done it when no crop-milk was present.

\footnotetext{
${ }^{32}$ Chabner (2017: 758-759), notes that prolactin from the anterior pituitary stimulates milk production, and after birth, sustains it.

${ }^{33}$ Levi notes "Apparently no other male animal or bird is known to create a 'milk'".

${ }^{34}$ Aristotle seems not to have complete knowledge of pigeon internal organs. In History of Animals II.XVII.506b 21-22, he says that pigeons have a gall-bladder near the intestines, but

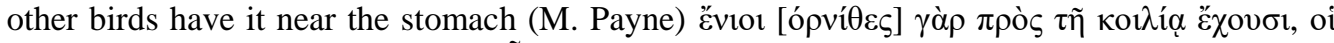

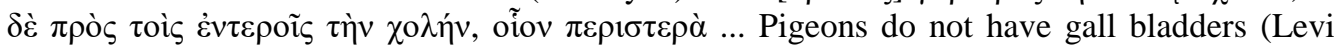
1974: 253); they have bile ducts, however (Levi 1974: 255).

${ }^{35}$ Arist. HA II.XVII. 508b.26-29. Trans. A.L. Peck, Cambridge, MA., 1965.
} 
A couple of other interesting points arise in looking at information both from Athenaeus and Aristotle. Athenaeus discusses pigeon brooding habits and how the male bird keeps the evil eye off the chicks by spitting on them (IX. 394b-c):

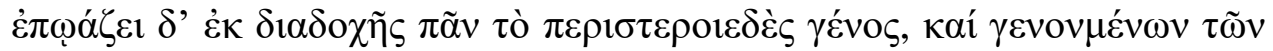

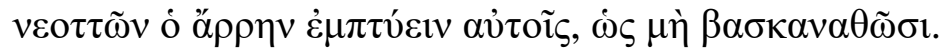

All pigeon varieties take turns brooding on their eggs, and when the chicks hatch, the male spits on them to keep off the evil eye ${ }^{36}$.

Aristotle, in turn discusses activities of the male bird, but for slightly different reasons. He says the male parent feeds the chicks by spitting into their mouths (HA VIII [IX].613a.3-6):

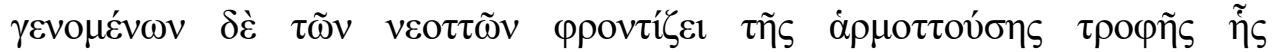

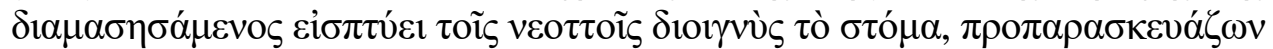

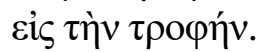

When the nestlings have come, he gives thought to suitable food, which he chews up and opening the nestlings' mouths spits into them, preparing them in advance for feeding ${ }^{37}$.

Both Atheneaus and Arisotole are accurate to some degree. Athenaeus, in saying that all pigeon varieties brood the eggs, he does not specify that only the male does this, as Aristotle says, thus he implies that both parents take turns in brooding, as is actually the case (Levi 1974: 368). He is less accurate, however, when he says that the male "spits on [the chicks] to keep off the evil-eye". While pigeons allow their chicks to take crop milk directly from their mouths, it is both parents who do the feeding, not just the male as Aristotle states. Aristotle is slightly more accurate in the method of feeding, but not in what is fed. First, the parents do not spit into the chicks' mouths, the chicks take the food from the parents' mouths. Second, the chicks do not eat food chewed-up by their parents, rather they eat a substance coming from the parent birds' crops. Neither author is cognizant of the crop-milk substance.

\section{Conclusion}

In conclusion, the proverbial phrase birds' milk (or hen's milk) has a long history from antiquity to the present. As something considered non-existent, it is a metaphor for rarity, impossibility and abundance, but on close examination, such an item actually exists. While the ancients may have had some indication about its existence in nature, those who use the phrase today

${ }^{36}$ Ath. IX. 394b-c. Trans. S. Douglas Olson, Cambridge, MA., 2008.

${ }^{37}$ Arist. HA VIII[X].613a.3-6. Trans. D.L. Balme, Cambridge, MA., 1991. 
do not. Exactly when people began using this phrase cannot be known, because, like myth, the phrase was probably passed down through oral tradition long before it was written down (Wheeler 1988: 153-154). Following Russo, one can see that the way the expression was used and the effect it was supposed to have on the hearers (1983: 121) is similar, if not the same in both ancient and modern contexts. In addition, the variant meanings of the expression in Modern Greek suggest that a similar understanding may have existed in the ancient languages. Future work with the phrase includes investigation to see if it can also be found in Byzantine Greek and medieval Latin sources. The fact that it appears in Late Antiquity, with Libanius, gives some hope that such might be the case. Nevertheless, the birds' milk phrase underscores the fact that such phrases, and their longer form, proverbs, preserve not only ancient traditional wisdom, but also give insight into the ancients' view of aspects pertaining to natural history.

\section{Acknowledgements}

Thanks to the following scholars who provided useful suggestions for this essay: Dr. Elizabeth Wolfram Thill and Dr. Glenn Snyder, both in the Classics Program, Indiana University-Purdue University at Indianapolis; Dr. Mixalis Poulakis, Department of Psychology, University of Indianapolis. Also thanks to my sister-in-law, Jacqueline Payne for her insight. Dedicated to the memory of my brother, William Payne, who loved birds; he raised pigeons and led me to the reality of birds' milk.

\section{References}

Barber R (1987) Blue Guide: Greece (5 ${ }^{\text {th }}$ ed.). New York: WW Norton.

Chabner D-E (2017) The Language of Medicine (11 ${ }^{\text {th }}$ ed.). St. Louis, Missouri: Elsevier.

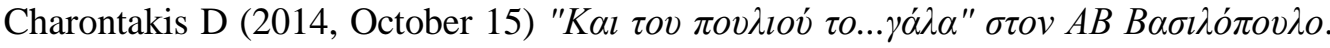
Bí $\mu \alpha$ (Vima). Retrieved from goo.gl/4nWxr7. [Accessed: 21 August 2016]

Cramp S, Simmons KEL (1985) Handbook of the Birds of Europe, the Middle East and North Africa: the Birds of the Western Palearctic. Volume IV: Terns to Woodpeckers. Oxford: Oxford University Press.

Dueck D (2004) Birds' Milk in Samos: Strabo's Use of Geographical Proverbs and Proverbial Expressions. Scripta Classica Israelica 23: 41-56.

Ehrlich PR, Dobkin DS, Wheye D (1988) Bird Milk. Retrieved from goo.gl/sIbYGQ. [Accessed: 31 July 2016]

Evans H, Heisser JB (2004) "What's Inside: Anatomy and Physiology". In S Podluka, RW Rohrbaugh, Jr., R Bonney (eds.), Handbook of Bird Biology ( $2^{\text {nd }}$ ed.). Ithaca, NY: Cornell Lab of Ornithology.

Foufopoulos J, Litinas N (2005) Crows and Ravens in the Mediterranean (the Nile Valley, Greece and Italy) as presented in Ancient and Modern Proverbial Literature. The Bulletin of the American Society of Papyrologists 42(1/4): 7-39. 
Handrinos G, Akriotis T (1997) The Birds of Greece. Christopher Helm Publishers Ltd.

Kindstrand JF (1978) The Greek Concept of Proverbs. Eranos 78: 71-85.

Lamberton RD, Rotroff SI (1985) Birds of the Athenian Agora. Vol. 22. Princeton, NJ: American School of Classical Studies at Athens.

Lardinois A (2001) The Wisdom and Wit of Many: The Orality of Greek Proverbial Expressions. Speaking Volumes: Orality and Literacy in the Greek and Roman World Supplement 218: 93-107.

Levi WM (1974) The Pigeon ( $2^{\text {nd }}$ edn.). Sumter, SC: Levi Publishing.

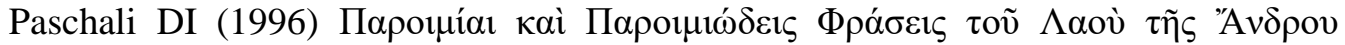

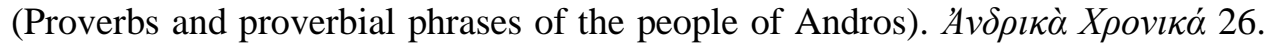
Andros.

Polunin O (1980) Flowers of Greece and the Balkans: A Field Guide. Oxford: Oxford University Press.

Russo J (1983) The Poetics of an Ancient Greek Proverb. Journal of Folklore Research 20(2/3): 121-130.

Sfikas G (1978) Wild Flowers of Greece. Athens: Efstathiadis.

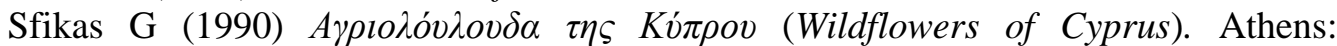
Efstathiadis

Shapiro S (2000) Proverbial Wisdom in Herodotus. Transactions of the American Philological Association 130: 89-118.

Storey IC (2011) The Poets of Old Comedy: Eupolis - Testimonia and Fragments. In IC Storey (eds. and trans.), Fragments of Old Comedy, Volume II: Diopeithes to Pherecrates. Harvard: Digital Loeb Classical Library, Harvard University Press.

Strömberg R (1954) Greek Proverbs: A Collection of Proverbs and Proverbial Phrases Which are not Listed by the Ancient and Byzantine Paroemiographers. Göteborg: Elander.

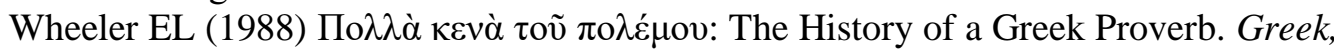
Roman and Byzantine Studies 29(2): 153-184.

Winkler D (2004) Nests, Eggs \& Young: Breeding Biology of Birds. In S Podluka, RW Rohrbaugh, Jr, R Bonney (eds.), Handbook of Bird Biology ( $2^{\text {nd }}$ edn.). Ithaca, NY: Cornell Lab of Ornithology. 